\title{
Education, Economic Growth \& Poverty Rate in Nigeria: Any Nexus?
}

\author{
Ehigiamusoe, Uyi Kizito \\ National Institute for Legislative Studies, National Assembly, Abuja, Nigeria \\ ehiuyikizexcel@yahoo.com
}

\begin{abstract}
Education is seen as a veritable tool for the socio-political and economic emancipation of any country from the shackles of ignorance, poverty, unemployment and low economic growth. But despite the enormous increase in education expenditure and literacy rate in Nigeria in the past two decades, noninclusive growth and high poverty rate still permeate all facets of human endeavour. In this light, the paper examines the interrelationships among education, economic growth and poverty in Nigeria. The study adopts econometrics methodology as the analytical tool using secondary data from 1980-2012. Evidence from the study suggests that though a long-run relationship exists among education, economic growth and poverty rate in Nigeria, but neither total education expenditure nor literacy rate cause changes in poverty rate in Nigeria. While government expenditure on education was found to have a positive and significant impact on economic growth (both in the short-run and in the long-run), literacy rate has positive but insignificant impact on growth. This could be due to high rate of unemployed school leavers, weak institutional mechanism, obsolete school curricula, shortage of critical infrastructure, and brain drain syndrome which characterize the country. The paper therefore recommended an increase in budgetary allocation to education as well as a review of the school curricula with a view to making the educational system more responsive to growth and poverty reduction in Nigeria. Government should also create the enabling environment for the creation of jobs through the provision of critical infrastructure which accelerate the development of small scale enterprises. This will provide gainful employment for school leavers and make them contribute more to inclusive growth and poverty reduction in Nigeria.
\end{abstract}

Keywords: Education, Economic Growth, Education Expenditure, Literacy Rate, Poverty Rate

\section{Introduction}

The symbolic relationship between education and economy rests on the belief that economic criteria are the basic considerations for investment in education. Therefore education and economy are regarded as mutually dependent to the extent that educational administrators have come to the consensus that education decisions should take account of its economic value as well as its contribution to economic growth. Enyi (1999) noted that investment in education rests on the logic that the educated earns more than the uneducated in most countries, and that the earning power of individual reflects their productivity level, which in turns is promoted by education. Also, economic development is related to individual's productivity level which means that more education leads to more economic development. Within a given occupation, a better educated person is likely to do a job better than a less educated one because additional education is expected to make an individual more aware of better ways of doing things (Ogbonnaya, 2006). According to Dauda (2009), the crucial role education plays in the overall development of a nation cannot be overemphasized because education is not only seen as a key to poverty reduction and vehicle for promoting equity, fairness and social justice but also helps to supply the essential human capital which is a necessary condition for sustained economic growth. Therefore, enhancing effective investment on education has been a tenet of growth and development strategies of most countries.

Blaug (1972) pointed out that the relationship between education and economy lies on the effect of literacy on the development of the economy. Education contributes to economic growth by improving the literacy level of the labour force and by helping in the acquisition of relevant skills and expertise. Eze (1983) submitted that the contribution of labour to economic growth varies positively with the length of period spent in schools. This long stay in school helps the individual in the acquisition and mastery of skills, which are required for effective production of goods and services. The acquisition of skills and expertise accelerates economic growth through higher job productivity and efficiency occasioned by a better mastery of the tools and techniques required for job performance. Countries with better skilled labour force develop faster and better than those with less skills especially if such countries posses the relevant management skills that will ensure that both human and physical resources are well blended and 
reconciled through effective planning, organizing, controlling, evaluating, and coordinating to desired results (Ogbonnaya, 2006). Education contributes to national development by fostering literacy; developing programmes to achieve national objectives; eliminating wasteful imbalances in the educational system; checking unemployment in the economy and judicious utilization of available resources. But Ogbonnaya (2006), see national development as the growth, changes and improvements occurring in a given economy with the aim of promoting the quality of life among the populace, poverty reduction inclusive. In essence, as the educational system in a country develops, the economy will continue to growth and poverty reduction will be accelerated.

A number of studies have been conducted to establish the relationship between education and economy. For instance, Anderson (1963) found evidence from his study to conclude that any country striving to increase its gross domestic product must first try to raise its literacy level. Similarly, Kaser (1966) discovered in his study that higher Gross National Income (GNI) per head is associated with higher enrolment ratio particularly at the secondary and tertiary levels of education. Bennett (1967) found evidence from his study to establish that vocational and general secondary education has high relationship with economic growth. Similarly, Peaslee (1967) showed that no country has ever achieved significant economic growth without first enrolling 10 per cent of the total population in primary schools. The overall implication of these reported studies is that the development of education system would very likely lead to rapid economic growth. However, despite the giant strides witnessed in the education sector in Nigeria in the last two decades which has resulted in the increased literacy rate and human capital development, economic growth has not been inclusive and poverty rate has been on the increase. This negates the assumption that the more the educational sector is developed, the more the economy grows and the more poverty is reduced. The Nigeria's situation seems pathetic because efforts by the three tiers of government at developing education have not been translated to increased gross domestic product and reduction in poverty. Vast majority of Nigerians live below one dollar per day with high rate of infant and maternal mortality, unemployment, income inequality and insecurity. Attempt is made therefore to examine the relationship between education and economic growth on the one hand, and between education and poverty on the other hand.

The broad objective of this paper is to examine the relationship among education, economic growth and poverty rate in Nigeria. Specifically, the paper seeks (i) to examine the impact of education on economic growth. (ii) To investigate the impact of education on poverty in Nigeria (iii) to prescribe policy options for Nigeria on how to utilize education as a vehicle for economic growth and poverty reduction. Following this introduction, the rest of the paper is structured into six sections. Section two presents the theoretical framework and the review of related literature, Section three contains the methodology and analytical framework adopted for the study. Section four presents the results of data analysis, while section five summarizes the major findings of the study. The final section recommends policy options for Nigeria and concludes the paper.

\section{Literature Review}

Traditionally, the theoretical linkage between education and economic growth lies on the fact that growth is attributed to the accumulation of human and physical capital, and increased productivity arising from technological innovation (Lucas, 1988). But human capital and technological innovation are the products of education, therefore, education causes growth. However, the theoretical basis for the impact of education on economic growth can be traced to the endogenous growth theory which stressed the importance of human capital for innovation and technical progress. The endogenous growth theory believes that economic growth is primarily the result of endogenous rather than exogenous variables. According to Romer (1994) one of the proponents of the endogenous growth theory, investment in human capital, innovation, and knowledge are significant contributors to economic growth. The theory also focuses on positive externalities and spill over effects of a knowledge-based economy which will lead to economic development. According to Babatunde \& Adefabi (2005), the proponents of the endogenous growth theory opine that improvements in productivity are related to a faster pace of innovation and extra investment in human capital. They further emphasize the need for government and private sector institutions and markets which nurture innovation to actively provide incentives for individuals to become more inventive and innovative. They also identify and lay emphasis on the central role of knowledge as a major determinant of economic growth (Babalola, 2011). The endogenous growth theory also asserts that the long run growth rate of an economy depends on some policy measures such as 
subsidies for Research and Development or education which increase the growth rate in some endogenous growth models by increasing the incentive for innovation.

Several studies have been conducted on the relationship between education and economic growth. Some of these studies empirically concluded that education has significant and positive impact on economic growth, while others claimed otherwise. For instance, Barro (1991) examined the relationship between expenditure on education and economic growth. He found out a positive and significant relationship between the level of school enrolment and the growth rate of real per capita output. Barro argued that an increase in the rate of investment in human capital development will help to close the development gaps between high and low income countries. Dauda (2009) empirically investigated the relationship between investment in education and economic growth in Nigeria, using annual time series data from 1977 to 2007. Employing Johansen cointegration technique and error correction methodology, the study showed that a long-run relationship exists between investment in education and economic growth. All the variables in his model namely, labour force, gross fixed capital formation and educational capital were positively and statistically significant (except labour force). This suggests that a concerted effort should be made by policy makers to enhance educational investment in order to accelerate growth which would engender economic development. Similarly, Omojimite (2010) examined the role of formal education in accelerating economic growth using data for the period 1980-2005. Time series econometrics (cointegration and granger causality test) were applied to test the hypothesis of a growth strategy led by improvements in the education sector. The results show that there is cointegration between public expenditures on education, primary school enrolment and economic growth. The study also showed that public expenditures on education granger cause economic growth but the reverse is not the case. The paper therefore recommended improved funding for the education sector and a review of the primary school curricula to make it more relevant to the needs of the Nigerian society.

The findings of Lawal \& Wahab (2011) are similar to the empirical results of Omojimite (2010) as they examined the relationship between education and economic growth in Nigeria using time series data for the period 1980-2008. The study adopted ordinary least squares technique and discovered that education investments have direct and significant impact on economic growth in Nigeria. They therefore recommended that government at all levels should increase their funding on different segments of education in the country. Odeleye (2012) examined the impact of education on economic growth using primary and secondary data from 1985-2007. The findings revealed that only recurrent expenditure of education sector has significant effects on economic growth, just as the academic qualifications of teachers also have significant impact on students' academic performance. The paper recommended increased government capital expenditure on education as well as incentives for teachers. Babatunde \& Adefabi (2005) using co-integration approach examined the long-run relationship between education and economic growth in Nigeria. The findings from their study revealed that a long-run relationship exists between education (enrolments in primary and tertiary levels of education as well as the average years of schooling) and output per worker. The study asserted that a well educated labour force have a positive and significant impact on economic growth through factor accumulation and on the evolution of total factor productivity.

Furthermore, Isola \& Alani (2012) examined the contribution of different components of human capital development to economic growth in Nigeria using growth account model. Empirical evidence from their study showed that education (measured by adult literacy rate) and health (measured by life expectancy) have positive and significant relationship with economic growth. This implies that both education and health components of human capital development are crucial to economic growth in Nigeria. Irughe (2013) empirically examines the impact of education expenditure on economic growth in Nigeria using data from 1977-2009. The study employed the error correction modelling technique and a geometric method of analyses and revealed that education expenditures have significantly negative effect on growth. He also discovered that the education expenditure in Nigeria followed a dwindling pattern and therefore recommended that public expenditure on education should maintain an upward budgetary allocation that is consistent since education is seen by many as a tool for national transformation. Owoeye \& Adenuga (2005) examined the impact of education and health expenditures on economic growth by estimating a parsimonious error correction model. The study discovered that education and health expenditures have positive and significant impact on economic growth. They recommended more allocation of resources to these important sectors where the private and social benefits are higher for the individual and the society, respectively. 
Babalola (2011) empirically evaluates the impact of education on economic growth in Nigeria using error correction method, Engle-Granger Approach and Johansen cointegration test. The results suggest that economic growth and education are integrated of order one while the Error Correction terms are integrated of order zero, which is a condition for the existence of cointegration. The study concluded that a long-run relationship exists between economic growth and education. Loening (2005) empirically examined the link between human capital development and economic growth. His findings revealed that a better educated labour force appears to have a positive impact on output growth. This empirical result contrasted the earlier work by Dorian (1997) who employed a neoclassical framework to estimate a structural growth model with education and health as exogenous variables. The findings from the study showed that while a positive and significant relationship exists between health and economic growth, the relationship between education and economic growth was found to be insignificant. Analogously, the nexus between education and poverty has also been documented by some researchers. As expected some of these studies provided empirical evidence to support the positive impact of education on poverty reduction while other proved otherwise. Njong (2010) investigated the role of education as a primary weapon against poverty using data from the 2001 Cameroonian Household Survey obtainable from the National Institute of Statistics. The study adopted a sample-selectivity corrected logistic regression model for estimation based on the cross-sectional data, with the probability of an individual being poor as the dependent variable and a set of educational levels and experience as explanatory variables. The results depicted that improvement in experience and educational attainments reduce the probability of being poor of the employed individual. On the gender side the study concluded that a male's educational level is more poverty reducing than a female counterpart.

Also, Awan et al. (2011) evaluated the effect of different levels of education, experience and gender of the employed individuals as the determinants of poverty using data from the Household Integrated Economic Survey (HIES) for the years 1998-99 and 2001-02. The study adopted a logistic regression model to estimate the data and found out that experience and educational achievement are negatively related with the poverty incidence in both years. They also discovered that as individual educational level increases, the probability of the person being non-poor also increases. Ahmad \& Imam (2013) examine the causality between poverty and education in Nigeria for the period 1970-2009, using Autoregressive Distributed Lag Procedure. The results of the study suggest a causal relationship between poverty and education both in the long-run and in the short-run periods. They found a one way relationship running from education to poverty. But, in the short-run, improvement in educational attainment does not reduce poverty. They therefore recommended an improvement in the standard of education provided in Nigeria so that education can play its role of welfare improvement and poverty reduction. Writing on the link between education and poverty, Ijaiya (1998) asserted that one of the strategies of poverty reduction is to ensure huge investment in education. This is because education is importance to economic development through increase in income, increase in entrepreneurship, better understanding and utilization of existing health facilities, etc. He recommended the involvement of the poor in the formulation and implementation of policies and programmes aimed at poverty reduction. From the review of related literature above, some studies have been conducted on the relationship between education and economic growth. Using different methods such as ordinary least squares method, co-integration analysis, etc, the results from these previous studies are mixed. But majority of the studies revealed a positive and significant relationship between education and economic growth. However, the literature on the link between poverty and education is still scanty. This present study intends to examine the impact of education on economic growth and poverty in Nigeria.

\section{Methodology}

Econometrics methodology is employed in this study as the analytical tool for the examination of the impact of education on economic growth. Consequently, the Ordinary Least Squares method is adopted to investigate the long-run relationship between education and economic growth. The Error Correction Model is also adopted to examine the short-run dynamics. The model states that economic growth is a function of Labour, Physical Capital, Human Capital, Total Education Expenditure and Adult Literacy Rate. To further examine the relationship among education, economic growth and poverty rate in Nigeria, the study employed Johanson's Cointegration Test. In order to test the direction of the relationship between education and poverty rate the study utilized Granger Causality Test. The secondary data used for this study covering the period 1980-2012 were obtained from the World Bank Database, Central Bank of Nigeria Statistical Bulletin, National Bureau of Statistics, Global Development Finance Statistics and International Development Statistics. 
Model Specification: The study adopts the augmented Solow growth model and introduced some measures of education to capture the impact of education on economic growth. Solow's (1956) model integrated human capital (in addition to labour and capital) as one of the independent variables in the growth model. The growth of national income is therefore specified as a function of increases in labour, physical capital and a residual representing all other factors. The aggregate production function used by Solow is continuous and homogenous of degree one and is specified as

$\mathrm{Y}=\mathrm{f}(\mathrm{L}, \mathrm{K}, \mathrm{T})$

Where: $\mathrm{Y}=$ Aggregate Real Output: $\mathrm{L}=$ labour: $\mathrm{K}=$ Capital: $\mathrm{T}=$ Technical Change.

Taking technical change constant, equation (1) becomes

$\mathrm{Y}=\mathrm{A} \mathrm{f}(\mathrm{L}, \mathrm{K})$

Re-writing equation (2) in growth terms and for estimation purpose gives

$\mathrm{GY}=\alpha^{0}+\alpha^{1} \mathrm{GK}+\alpha^{2} \mathrm{GL}+\mathrm{U}$

In order to examine the impact of education on economic growth, variables such as total public education expenditure, adult literacy rate and tertiary school enrolment rate were introduced into the models to capture the relationship between education and economic growth as specified in equation (4)

$\mathrm{RGDP}=\alpha_{0}+\alpha_{1} \mathrm{~L}+\alpha_{2} \mathrm{~K}+\alpha_{3} \mathrm{HK}+\alpha_{4} \mathrm{EDEX}+\alpha_{5} \mathrm{LITR}+\mathrm{U}$

Where:

RGDP = Real Gross Domestic Product, proxy for Economic Growth

$\mathrm{L}=$ Labour

$\mathrm{K}=$ Physical Capital

HK = Human Capital proxied by tertiary school enrolment rate

EDEX = Total Education Expenditure

LITR = Adult Literacy Rate

$\mu=$ error term

$\alpha_{0}, \alpha_{1}, \alpha_{2}, \alpha_{3}, \alpha_{4} \& \alpha_{5}=$ parameters to be estimated

The a priori expectations are $\alpha_{1}>0, \alpha_{2}>0, \alpha_{3}>0, \alpha_{4}>0 \& \alpha_{5}>0$

\section{Data Analysis and Results}

Unit Root Tests: The unit root test was conducted to ascertain the stationarity of the data before estimation using both the Augmented Dickey Fuller (ADF) and the Philips-Perron (PP). The results of the test presented in Table 1 shows that all the variables (except human capital and literacy rate) are stationary at level at 1 per cent significant level. Human capital and literacy rate are stationary at first difference at 1 per cent significant level.

Table 1: Unit Root Test Results

\begin{tabular}{|c|c|c|c|c|c|}
\hline \multirow[t]{2}{*}{ Variables } & \multicolumn{2}{|l|}{ ADF Test Statistic } & \multicolumn{2}{|c|}{ Philips-Perron Test Statistic } & \multirow[t]{2}{*}{ Conclusion } \\
\hline & Level & $1^{\text {st }}$ Difference & Level & $1^{\text {st }}$ Difference & \\
\hline RGDP & $-3.887678^{*}$ & -7.478464 & $-3.887678 *$ & -11.21530 & $\mathrm{I}(0)$ \\
\hline $\mathrm{L}$ & $-5.057361^{*}$ & -9.443407 & $-26.38254 *$ & -48.83359 & $\mathrm{I}(0)$ \\
\hline $\mathrm{K}$ & $-6.593542 *$ & -11.64149 & $-6.533110 *$ & -11.78056 & I(0) \\
\hline HK & -0.587516 & $-4.265148 *$ & -0.516179 & $-5.951414 *$ & I(1) \\
\hline EDEX & $-4.801596^{*}$ & -7.096380 & $-5.421455^{*}$ & -10.98607 & $\mathrm{I}(0)$ \\
\hline LITR & -0.182574 & $-3.872983^{*}$ & -0.243302 & $-5.569109^{*}$ & $1(1)$ \\
\hline $1 \%$ Critical Value & -3.6496 & -3.6496 & -3.6496 & -3.5973 & \\
\hline $5 \%$ Critical Value & -2.9558 & -2.9558 & -2.9558 & -2.9339 & \\
\hline $10 \%$ Critical Value & -2.6164 & -2.6164 & -2.6164 & -2.6048 & \\
\hline
\end{tabular}

*indicates significant at $1 \%$ or a rejection of the null hypothesis of no unit root at the $1 \%$ significant level

Therefore, the hypotheses that state the presence of unit roots in all the variables under consideration are rejected for real gross domestic product, labour, physical capital, and education expenditure, but accepted for human capital and literacy rate at 1 per cent significant level.

Johansen Cointegration Test Results: The Johansen Cointegration test result in Table 2 shows the existence of two cointegrating equations at 5\% significance level in the model. The hypotheses that state there are no long-run relationship among education, economic growth and poverty rate are rejected at $5 \%$ significance level. This implies that there exists a long-run relationship among education, economic growth and poverty rate in Nigeria. 
Date: 11/04/13 Time: 10:16

Sample: 19802012

Included observations: 31

Test assumption: Linear deterministic trend in the data

Series: RGDP L K HK LITR EDEX POV

Lags interval: 1 to 1

Table 2: Johansen Cointegration Test Results

\begin{tabular}{llllr}
\hline Eigen value & $\begin{array}{l}\text { Likelihood } \\
\text { Ratio }\end{array}$ & $\begin{array}{l}\text { S Percent } \\
\text { Critical } \\
\text { Value }\end{array}$ & $\begin{array}{l}\text { 1 Percent } \\
\text { Critical Value }\end{array}$ & $\begin{array}{l}\text { Hypothesized } \\
\text { No. of CE(s) }\end{array}$ \\
\hline 0.890492 & 171.3167 & 124.24 & 133.57 & None ** \\
0.783121 & 102.7522 & 94.15 & 103.18 & At most ${ }^{*}$ \\
0.497739 & 55.37134 & 68.52 & 76.07 & At most 2 \\
0.438442 & 34.02367 & 47.21 & 54.46 & At most 3 \\
0.292979 & 16.13545 & 29.68 & 35.65 & At most 4 \\
0.158489 & 5.387901 & 15.41 & 20.04 & At most 5 \\
0.001246 & 0.038645 & 3.76 & 6.65 & At most 6 \\
\hline
\end{tabular}

$\left.{ }^{*}{ }^{* *}\right)$ denotes rejection of the hypothesis at 5\%(1\%) significance level

L.R. test indicates 2 cointegrating equation(s) at 5\% significance level

Long Run Regression Results: Having conducted the unit root and cointegration tests, we proceeded to obtain the long-run relationship between education and economic growth using the ordinary least squares method. The result presented in Table 3 reveals that all the variables in the model satisfy the a priori expectations with respect to their signs. Physical capital, human capital and total education expenditure have positive and significant impact on growth, while the impact of labour and literacy rate on economic growth is positive but insignificant (at 10 per cent significant level.) in the long-run. However, a unit increase in physical capital, human capital and total education expenditure will increase economic growth by 4.9 per cent, 8.1 per cent and 22.5 per cent, respectively. The adjusted $\mathrm{R}^{2}$ of 71.9 per cent indicates the variations in the dependent variable that are explained by variations in the independent variables and the Durbin Watson statistic of 1.7 suggests that the model is free from serial auto correlation.

Dependent Variable: RGDP

Method: Least Squares

Date: 11/04/13 Time: 08:54

Sample: 19802012

Included observations: 33

Table 3: Long Run Regression Results

\begin{tabular}{|c|c|c|c|c|}
\hline Variable & Coefficient & Std. Error & t-Statistic & Prob. \\
\hline $\mathrm{C}$ & -6.884059 & 22.46286 & -0.306464 & 0.7616 \\
\hline $\mathrm{L}$ & 6.678817 & 8.458481 & 0.789600 & 0.4366 \\
\hline $\mathrm{K}$ & 0.049480 & 0.018108 & 2.732590 & 0.0109 \\
\hline HK & 0.812089 & 0.257727 & 3.150970 & 0.0040 \\
\hline EDEX & 2.250657 & 0.842725 & 2.670691 & 0.0127 \\
\hline LITR & 0.058245 & 0.415250 & 0.140265 & 0.8895 \\
\hline R-squared & 0.810088 & \multicolumn{2}{|c|}{ Mean dependent var } & 3.760606 \\
\hline Adjusted R-squared & 0.719363 & \multicolumn{2}{|c|}{ S.D. dependent var } & 4.942288 \\
\hline S.E. of regression & 3.766000 & \multicolumn{2}{|c|}{ Akaike info criterion } & 5.652870 \\
\hline Sum squared resid & 382.9345 & \multicolumn{2}{|c|}{ Schwarz criterion } & 5.924962 \\
\hline Log likelihood & -87.27235 & \multicolumn{2}{|c|}{ F-statistic } & 5.622381 \\
\hline Durbin-Watson stat & 1.688333 & \multicolumn{2}{|c|}{ Prob(F-statistic) } & 0.001121 \\
\hline
\end{tabular}

Vector Error Correction Model Results: To capture the short-run dynamics using the residuals from the co-integration regression as the error correction term, the estimated coefficient of the error correction term ECM (-1) shows a negative $(-0.489130)$ and statistically significant values in terms of its associated $\mathrm{t}$-value $(-2.127476)$ and probability value $(0.0448)$. Starting with the over-parameterised model, we then tested down (dropping the variables with low t-statistic) until we arrived at our preferred parsimonious 
model as shown in Table 5. The result reveals that all the variables in the model (except the two period lagged value of capital) satisfy the a priori expectations with respect to their signs. The two period lagged value of capital has a negative impact on economic growth in the short-run. But physical capital, human capital and total educational expenditure have positive and significant impact on growth. This means that a unit increase in physical capital, human capital and total educational expenditure will increase economic growth by 3.0 per cent, 9.5 per cent and 27.8 per cent, respectively. Though the lagged value of total educational expenditure is positively related to growth, but its impact is not statistically significant. The adjusted coefficient of determination $\left(\mathrm{R}^{2}\right)$ of 76.8 per cent shows a reasonable explanatory power of the model as 76.8 per cent of the variations in the endogenous variable is accounted for by variations in the exogenous variables. The F-statistics of 4.3 suggests that good interactive feedback effect exists within the model, while the Durbin Watson statistic of 1.91 indicates a good fit and an absence of autocorrelation.

Dependent Variable: RGDP

Method: Least Squares

Date: 11/04/13 Time: 09:56

Sample(adjusted): 19822012

Included observations: 31 after adjusting endpoints

Table 4: Short-Run Parsimonious Model Results

\begin{tabular}{lllll}
\hline Variable & Coefficient & Std. Error & t-Statistic & Prob. \\
\hline C & -4.599942 & 2.186942 & -2.103367 & 0.0471 \\
K & 0.030450 & 0.015885 & 1.916918 & 0.0683 \\
HK & 0.957481 & 0.240534 & 3.980642 & 0.0006 \\
EDEX & 2.783848 & 0.830934 & 3.350263 & 0.0029 \\
EDEX(-1) & 0.474478 & 0.751482 & 0.631389 & 0.5343 \\
L(-2) & 13.15737 & 9.586740 & 1.372455 & 0.1838 \\
K(-2) & -0.026746 & 0.015687 & -1.704935 & 0.1023 \\
EDEX(-2) & 1.147943 & 0.718100 & 1.598585 & 0.1242 \\
ECM(-1) & -0.489130 & 0.229911 & -2.127476 & 0.0448 \\
R-squared & 0.810027 & Mean dependent var & 4.290323 \\
Adjusted R-squared & 0.768218 & S.D. dependent var & 4.035125 \\
S.E. of regression & 2.942549 & Akaike info criterion & 5.234130 \\
Sum squared resid & 190.4891 & Schwarz criterion & 5.650449 \\
Log likelihood & -72.12901 & F-statistic & 4.301767 \\
Durbin-Watson stat & 1.917849 & Prob(F-statistic) & 0.003083 \\
\hline
\end{tabular}

Granger Causality Tests: The granger causality tests result presented in table 5 shows that there is no causality between literacy rate and labour, total education expenditure and labour, poverty rate and total education expenditure, as well as human capital and education expenditure. Therefore the hypotheses that state the absence of causality between these variables are accepted at $10 \%$ significant level. This means that a change in education expenditure and literacy rate do not cause a change in labour, human capital and poverty rate. This result disagreed with the result of Omojimite (2010) whose finding showed that public expenditures on education granger cause economic growth as well as the existence of a bidirectional causality between public recurrent expenditure on education and economic growth. He, however discovered that pubic capital expenditure does nor granger cause economic growth, the same way primary school enrolment rate was discovered not to granger cause economic growth. However poverty rate granger cause literacy rate, human capital and labour. This implies that a change in poverty rate will cause a change in labour, human capital and literacy rate. This test result reveals that education variables (total education expenditure, human capital and literacy rate) do not cause a change in poverty rate in Nigeria.

Summary of Major Findings and Policy Implications: The summary of the findings of the study are as follows: Firstly, a long-run relationship exists among education, economic growth and poverty rate in Nigeria. This finding corroborate the finding of Dauda (2009) who discovered that a long-run relationship exists between investment in education and economic growth. But the study found out that neither total education expenditure nor literacy rate produce changes in poverty rate in Nigeria. A change in poverty rate was found to cause changes in labour growth rate, human capital and literacy rate. No causality was found to run from education to poverty rate in Nigeria. This finding agreed with those of Moulton (2001), 
Flor et al. (2006) and Aref (2011) who examined the relationship between education and poverty and discovered that though education has impact on rural poverty reduction, but since poverty is multidimensional, rural educational system cannot solve the poverty problems. Secondly, government expenditure on education was found to have a positive and significant impact on economic growth both in the short-run and in the long-run in Nigeria. This means that government can accelerate economic growth by increasing total expenditures on education. This finding give credence to the finding of Anyanwu and Erhijakpor (2007) who discovered that government expenditure on education has positive and significant impact on economic growth as well as the achievement of Millennium Development goals. However, the finding of Irughe (2013) is not in consonant with this finding, because he found out that education expenditure has a negative and significant impact on economic growth.

Pairwise Granger Causality Tests

Date: $11 / 04 / 13$ Time: 10:25

Sample: 19802012

Lags: 2

\begin{tabular}{lcccl} 
Table 5: Granger Causality Test & \multicolumn{7}{l}{} \\
\hline Null Hypothesis: & Obs & F-Statistic & Probability & Conclusion \\
\hline POV does not Granger Cause L & 31 & 3.12984 & 0.06054 & Rejected $^{*}$ \\
L does not Granger Cause POV & & 0.20298 & 0.81758 & Accepted \\
HK does not Granger Cause K & 31 & 5.88802 & 0.00778 & Rejected* \\
K does not Granger Cause HK & \multirow{3}{*}{31} & 0.50987 & 0.60646 & Accepted \\
LITR does not Granger Cause HK & & 1.16968 & 0.32627 & Accepted \\
HK does not Granger Cause LITR & 31 & 3.99444 & 0.03071 & Rejected* \\
POV does not Granger Cause HK & & 0.48688 & 0.62003 & Accepted \\
HK does not Granger Cause POV & 31 & 3.05118 & 0.06452 & Rejected* \\
POV does not Granger Cause LITR & & 2.04509 & 0.14967 & Accepted \\
LITR does not Granger Cause POV & \multirow{2}{*}{31} & 0.59962 & 0.55644 & Accepted \\
POV does not Granger Cause EDEX & & 0.03839 & 0.96239 & Accepted \\
EDEX does not Granger Cause POV &
\end{tabular}

Note: Rejecting the null hypothesis means that one variable actually granger cause the other: while accepting the null hypothesis confirms that there is no causation between both variables at 10\% significance level.

Thirdly, though literacy rate has positive impact on economic growth in Nigeria, but its impact is not statistically significant both in the short-run and in the long-run. This implies that the present state of adult literacy rate in Nigeria cannot be used as a vehicle to accelerate economic growth in Nigeria. This finding did not support the finding of Isola \& Alani (2012) who empirically concluded that adult literacy rate has a positive and significant on economic growth. Furthermore, the study discovered that human capital has a positive and significant impact on economic growth both in the short-run and in the long-run in Nigeria. This means that the government can increase economic growth by investing in the development of human capital. This finding is in conformity with the finding of Barro (1991) who also discovered that an increase in the rate of investment in human capital development will help to close the gap between high and low income countries. Finally, the growth rate of physical capital was found to have a positive and significant impact on economic growth both in the short-run and long-run while labour growth rate shows positive relationship with economic growth.

\section{Conclusion \& Policy Options}

Education is seen as a veritable tool for the socio-political and economic emancipation of any country from the shackles of ignorance, poverty, unemployment and low economic growth. But despite the enormous increase in education expenditure and literacy rate in Nigeria in the past two decades, noninclusive growth and high poverty rate still permeate all facets of human endeavour. In this light, the paper examines the interrelationships among education, economic growth and poverty in Nigeria. The study adopts econometrics methodology as the analytical tool using secondary data from 1980-2012. Evidence from the study suggests that though a long-run relationship exists among education, economic growth and poverty rate in Nigeria but neither total education expenditure nor literacy rate cause changes in poverty rate in Nigeria. While government expenditure on education was found to have a positive and significant impact on economic growth (both in the short-run and in the long-run), literacy 
rate has positive and insignificant impact on growth. This could be due to high rate of unemployed school leavers, weak institutional mechanism, obsolete school curricula, shortage of critical infrastructure, and brain drain syndrome which characterize the country. The paper therefore recommended an increase in budgetary allocation to education as well as a review of the school curricula with a view to making the educational system more responsive to growth and poverty reduction in Nigeria. Government should also create the enabling environment for the creation of jobs through the provision of critical infrastructure which accelerate the development of small scale enterprises. This will provide gainful employment for school leavers and make them contribute more to inclusive growth and poverty reduction in Nigeria.

\section{References}

Ahmad, H. S. \& Imam, M. Z. (2013). A Study of Causality between Poverty and Education in Nigeria. Paper presented at the $4^{\text {th }}$ National Conference on Education in SRCOE, Kano from $10^{\text {th }}-13^{\text {th }}$ September, $1-14$

Anderson, A. (1963). Education and Growth. In Ogbonnaya, N. (2006) Economics of Education. National Open University of Nigeria Publications, Midland Press Ltd, Jos. 1-30

Anyanwu, J. C. \& Erhijakpor, A. E. 0. (2007). Education Expenditure and school enrolment in Africa: Illustration from Nigeria and other SANE Countries. A paper presented in NES Annual Conference in 2007, 261-285.

Aref, A. (2011). Perceived Impact of Education on Poverty Reduction in Rural Areas of Iran. Life Science Journal, 8(2), 498-501

Awan, M. S., Malik, N., Sarwar, H. \& Waqas, M. (2011). Impact of Education on Poverty Reduction. International Journal of Academic Research, 3(1), 659-664.

Babalola, S. J. (2011). Long-Run Relationship between Education and Economic Growth: Evidence from Nigeria. International Journal of Humanities and Social Sciences, 1(14), 123-128.

Babatunde, M. A. \& Adefabi, R. A. (2005). Long-Run relationship between Education and Economic growth in Nigeria: Evidence from Johannes's cointegration Approach. Paper presented at the Regional conference on education in West Africa: constraints and opportunities. Dakar Senegal Nov. 1st 2nd 2006.

Barro, R. J. (1991). Economic Growth in a Cross Section of Countries. Quarterly Journal of Economics, 106, $407-443$.

Bennett, W. S. (1967). Educational Change and Economic Development. Sociology of Education, spring, 110

Blaug, M. (1972). An Introduction to Economics of Education. Barmondsworth: Penguin Books, pp.1-5

Dauda, R. O. (2009). Investment in Education and Economic Growth in Nigeria: A Cointegration Approach. Paper presented at the 9th Global Conference on Business \& Economics, October 16-17 Cambridge University, U.K. 1-15

Dorian, S. K. (1997). Education and Health in an Effective - Labour Empirical Growth Model. The Economic Record, 73, $314-328$.

Enyi, D. (1999). Fundamentals of Educational Planning. (Mimeograph) Nsukka: Department of Educational Foundation, University of Nsukka, 1-6

Eze, A. (1983). Economics of Education: The Nigerian Experience. Owerri, New Africa Publication Company, 10-13

Flor, A. G., Hazelman, M. \& McLean, S. (2006). Agricultural development and rural poverty reduction: A comparative analysis of Innovation and best practice in Asia and the Pacific, 1-6

Ijaiya, G. T. (1998). Alleviating Poverty in Nigeria: Investing in Education as a Necessary Recipe. Ilorin Journal of Education, 18(1), 125-131.

Irughe, I. R. (2013). The Impact of Educational Expenditure on Economic Growth in Nigeria: An Error Correction Specification. The Social Sciences, 8(2), 206-212.

Isola, W. A. \& Alani, R. A. (2012). Human Capital Development and Economic Growth: Empirical Evidence from Nigeria. Asian Economic and Financial Review, 2(7), 813-827.

Kaser, M. (1966). Education and Economics Progress: Experience in Industrialized market Economies, in Robinson, E.A. \& Valzy, J. (Eds) The Economics of Education. London, Macmillan, pp.1-5

Lawal, A. \& Wahab, T. I. (2011), Education and Economic Growth: The Nigerian Experience. Journal of Emerging Trends in Economics and Management Sciences, 2(3), 225-231.

Loening, J. L. (2005). Effects of Primary, Secondary and Tertiary Education: Evidence from Guatemala. Policy Research Working Paper (3610).

Lucas, R. E. (1988). On the Mechanics of Economic Development, Journal of Monetary Economics, 22(1), 3-42. 
Moulton, J. (2001). Improving Education in Rural Areas: Guidance for Rural Development Specialists. Pp.1-12

Njong, A. M. (2010). The Effects of Educational Attainment on Poverty Reduction in Cameroon. Journal of Education Administration and Policy Studies, 2(1), 001-008.

Ogbonnaya, N. (2006). Budgeting and Financial Management in Education. National Open University of Nigeria Publications, Midland Press Ltd, Jos. Pp 1-20

Omojimite, B. U. (2010). Education and Economic Growth in Nigeria: A Granger Causality Analysis. African Research Review, An International Multi-Disciplinary Journal, Ethiopia, 4 (3a), 90-108

Odeleye, A. T. (2012). Education and Economic Growth in Nigeria: A Comparative Analytical Approach. European Journal of Globalization and Development Research, 5(1), 329-342.

Owoeye, T. \& Adenuga, D. S. (2005). Human Capital and Economic Development: An Empirical Analysis of a Developing Economy (1970 - 2000) A working paper. University of Ado-Ekiti, Nigeria. Pp.10-14

Peaslee, A. L. (1967). Primary School Enrolments and Economic Growth. Comparative Education Review, February, pp.13-16

Romer, P. M. (1994). The Origins of Endogenous Growth. The Journal of Economic Perspectives, 8(1), 3-12.

Solow, R. M. (1956). A Contribution to the Theory of Economic Growth. The Quarterly Journal of Economics, 70 (1), 65-94. 